Indonesian Journal of Physics and Nuclear Applications

Volume 2, Number 3, October 2017, p. 101-110

e-ISSN 2550-0570, (C) FSM UKSW Publication

\title{
CREATIVE ENVIRONMENTAL ENERGY TECHNOLOGY ASSESSMENT HYDROELECTRIC POWER PLANT (CASE STUDY OF WONOGIRI RESERVOIR)
}

\author{
Feby Hidayani'), Yohanes Sardjono ${ }^{2)}$, Chafid Fandeli'), Rukmini A.R ${ }^{1)}$ \\ 1) Pascasarjana Institut Teknologi Yogyakarta \\ 2) Pusat Sains dan Teknologi Akselerator BATAN
}

\begin{abstract}
Hydroelectric power plants in Indonesia are widely developed. This is because the water supply in Indonesia is quite abundant. Several large reservoirs in Indonesia, in addition to being used for water reservoirs, are used to produce electricity. Wonogiri is a region that is located in Central Java province, where most of the region is arid land that cannot be planted in the dry season. In the rainy season the abundance of water plants to die and the soil is such that in the dry season crops do not grow well. Plans for the construction of Gajah Mungkur started in 1964, and it is designed to be a multipurpose dam project that aim to control floods, supply water for irrigation and hydropower in the Solo River valley. The master development plan was formulated in 1972-1974 with the help of Overseas Technical Cooperation of Japan. The results of this study include the completion of flooding problems along the Solo River, the increase in agricultural output in Winton community with irrigation facilities and good infrastructure, availability of electricity for communities around the dam and improving the local economy as the development of inland fisheries and tourism sectors.
\end{abstract}

Keywords hydroelectric power plants reservoirs, Wonogiri, process, development

\section{INTRODUCTION}

A hydro power plant is one source of electrical energy that utilizes water as a source of electricity. This plant is one of the main sources of electrical energy in Indonesia. Its existence is expected to meet the electricity supply for the people of Indonesia, other than those derived from coal fuel. Hydroelectric power plants in Indonesia are widely developed. This is because the water supply in Indonesia is quite abundant. Several large reservoirs in Indonesia, in addition to being used for water reservoirs, have the potentional to be used to produce electricity Hydroelectricity development is one of them due ato the potential due to the abudance of water in Indonesia. In Indonesia alone there are ten hydropower plants, such as Singkarak
(West Sumatera), Gajah Mungkur (Central Java), Karangkates (East Java), Riam Kanan (South Kalimantan), and Larona (South Sulawesi). An abundant amount of water is needed to create energy converted into an electric current. This is intended to create a low cost of production of electricity in Indonesia. The hydroelectric power plant is one of the oldest sources of power ever found. In addition to these plants, there are also some types of power plants in the world including solar power plants, diesel power plants, and also nuclear power plants. Hydropower works by changing potential energy (from DAM or waterfall) to mechanical energy (with the help of water turbines) and from mechanical energy to electrical energy (with the help of generators).

The flood that occurred in Surakarta in March 1966 with the peak discharge in Jurug of 
$1978 \mathrm{~m}^{3} / \mathrm{second}$ is the largest flood ever to occur in the Bengawan Solo River Basin. This flood had a puddling area of 10,000 ha, in the city of Surakarta of 1000 ha and in the Sragen area of 8,000 ha. Gajah Mungkur Reservoir located in the south of Wonogiri Regency was built with the main purpose of flood control that often occurs due to the overflowing Bengawan Solo river in the rainy season. In addition, agricultural irrigation is also an important consideration given that most of the people living around it are farmers and planters. With the availability of irrigation facilities and infrastructure, this reservoir as a pemengakap to regulate the entry and discharge of running water. This control is very beneficial because it can regulate the flow of water in the rainy season so that floods can be controlled. And in the dry season, the reservoir is an important source of water for community agricultural facilities.

In addition, the construction of Gajah Mungkur Reservoir is expected to change the economic condition of surrounding communities by utilizing the potential that will be generated by the reservoir. Potentials that are expected to grow along with the construction of dams are fisheries, electricity and tourism sectors.

\section{MATERIAL AND METHOD}

Wonogiri Reservoir is also called the Gajah Mungkur Dam, located in Danuarjo Village, Wonogiri District, Wonogiri Regency, Central Java Province. Wonogiri Reservoir, which has a wide catchment area of $1350 \mathrm{~km}^{2}$ is located $3 \mathrm{~km}$ south of Wonogiri Regency. Construction of Wonogiri Reservoir began in 1976. The first filling was carried out in July 1980 and then inaugurated in November of the same year. The main benefits of the Wonogiri Reservoir are for flood control, hydropower, irrigation, and drinking water.

\section{a. Data collection}

- Data on reservoir characteristics

- Data requirements downstream

- Data on hydropower installation

- Other supporting data

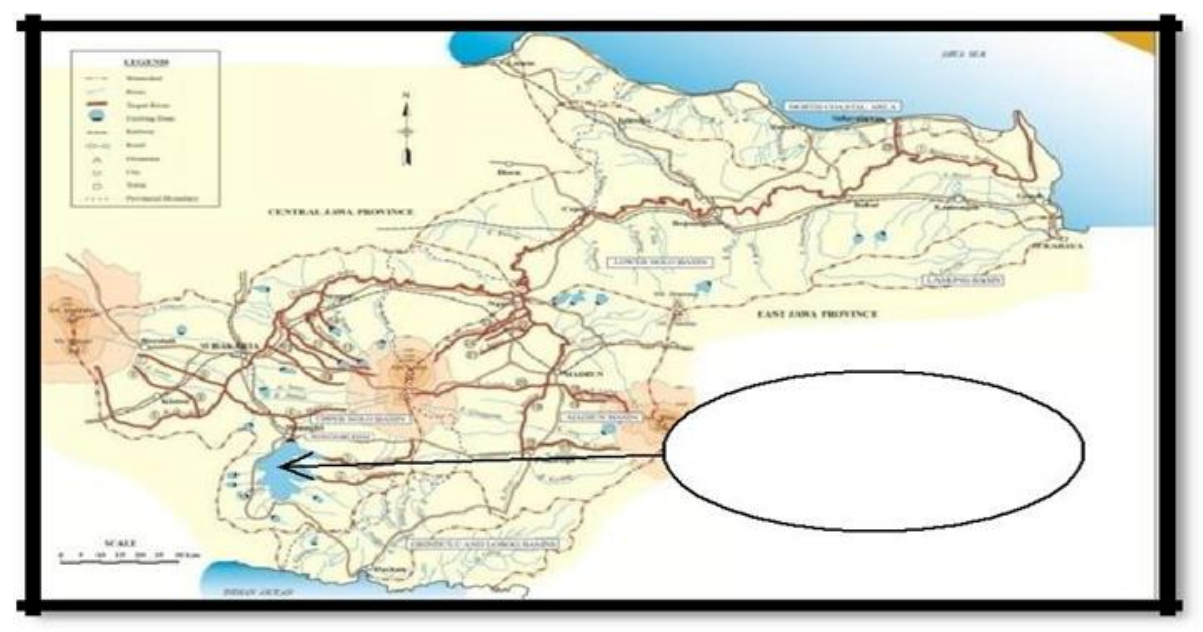

Figure 1. Map of Wonogiri Reservoir Location Source: BBWS Bengawan Solo

\section{b. Planning of hydroelectricity}


- High inertia (head) is easy to obtain, abundant amount of water, and good flow state

- Good geographic and geological location for dams, central buildings and other constructions

- Materials for concrete, dams, etc. are easily available for the project

- It is good for transporting construction materials and heavy equipment
- Problems arising from the project are easily solved

- Low transmission costs

- Rainfall is expressed by the high water in a tube, usually in $\mathrm{mm}$

Stream flow or discharge is the amount of water flowing through a particular river cross section per unit of time

\section{c. Scheme and process of Hydro Power Plant}

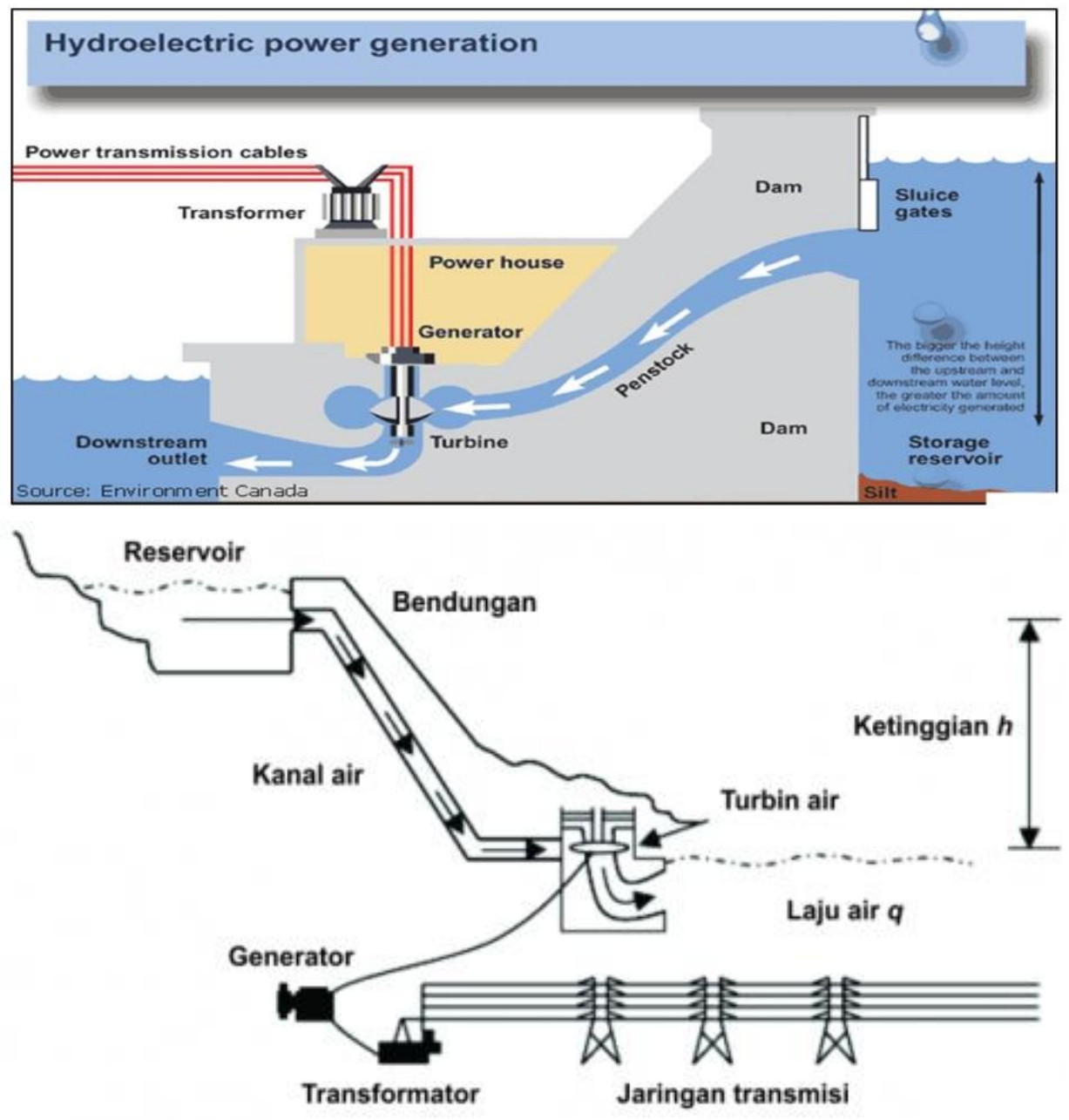

Figure. 2 Chart. PLTA in general converts the potential energy of water (gravity 
energy of water) into electrical energy, the driving machine used is a water turbine to convert the potential energy of water into a shaft mechanical work that will turn the generator to produce electrical energy. Water as a raw material for hydropower can be obtained from the river directly channeled to rotate the turbine by being collected first (along with rain water) by using tando pond or reservoir before it is channeled to rotate the turbine. The electric power generated can be calculated using the formula approach:

\section{P=9,8 Q X H X ít $x$ íg....(kW)}

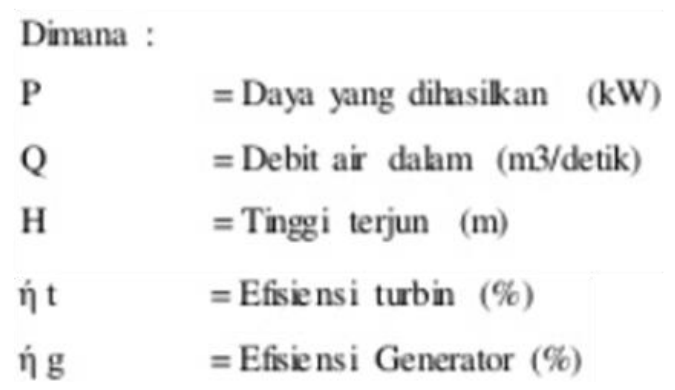

- Water flows through an adjustable water gate to obtain the desired water discharge.

- This water flow will pass through the pipe rapidly and cause increased water pressure.

- The water from the pipe will then crash into the turbine blades so that the turbine can rotate.

- Rotation of the turbine connected to the shaft will make the rotor generator also spin.
- The rotating generator causes a change of magnetic field between the stator and the rotor so that there will be emf (electron flow).

Generator-generated electricity will be fed to the step up transformer.

\section{d. Major Component of Hydro Power Plant}

\section{- Dam}

The dam is a component part of the Water Hydroelectric Power that serves to hold large amounts of water and to create a high water fall so that the power generated is also large. In addition, the dam also serves to control flooding

\section{- Turbine}

Turbine is a very important component in Power Plant. Turbine works to convert the flow of water into mechanical energy. Falling water will drive the propeller causing the turbine to spin. This turbine rotation is connected to the generator. Water turbines are mostly shaped like windmills

\section{- Generator}

The generator is a component connected to a turbine where the generator will generate electrical energy. The generator works like any other generator in the hydropower plant or another generator, which converts mechanical energy into electrical energy according to the characteristics supplied. 


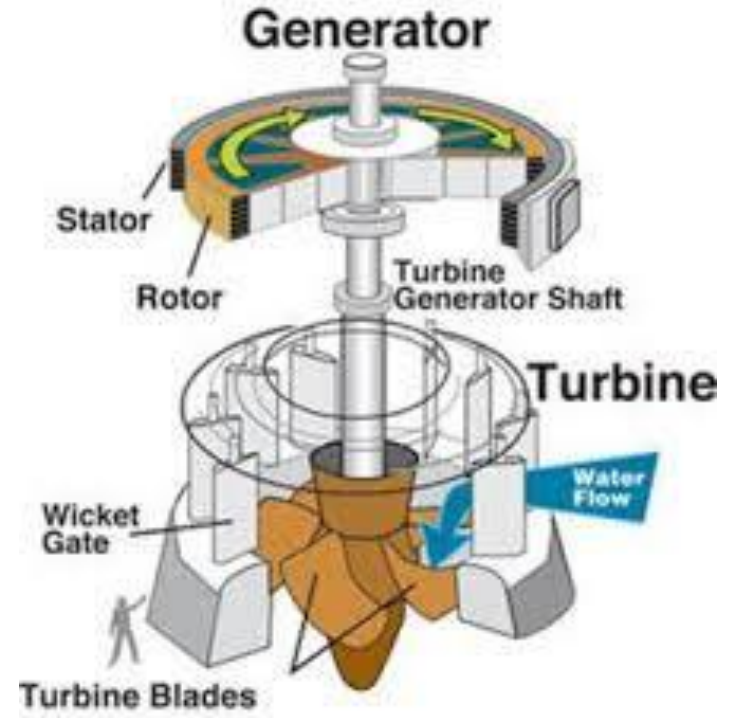

- Transmission line

It functions to drain electrical energy from hydropower to homes and industrial centers.

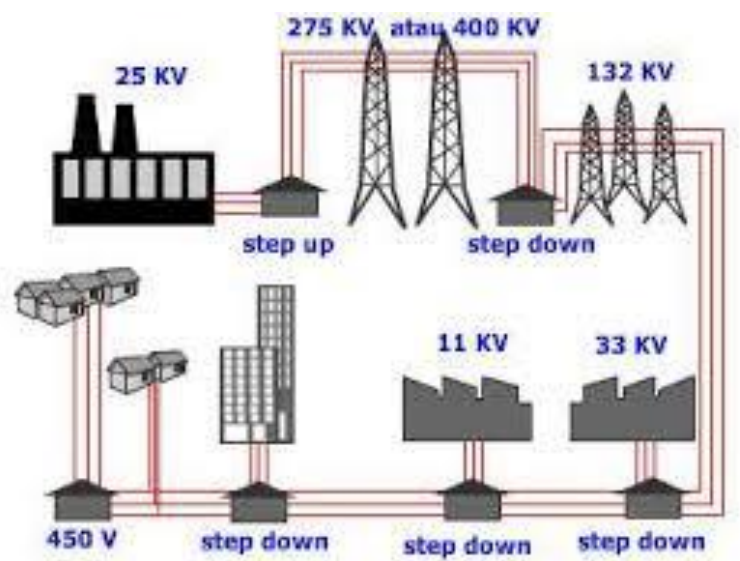

\section{e. Principle of Hydropower and Energy Conversion}

In principle, the hydroelectric power plant converts the potential energy of water into kinetic energy in the presence of the head, then kinetic energy is transformed into mechanical energy by the flow of water that drives the turbine, then the mechanical energy is transformed into electrical energy through the rotation of the rotor of the generator. The amount of electrical energy that can be generated by water resources depends on two things, namely the distance of the water (head) and how much water flows (debit). To be able to generate electrical energy from water, there are several stages of energy changes, namely :

- Potential energy

Potential energy is the energy that occurs due to the potential difference, that is due to the difference in height. The amount of potential energy is:

$\mathrm{Ep}=\mathrm{m} \cdot \mathrm{g} \cdot \mathrm{h}$

Explanation :

Ep : Energi Potensial (potential energy)

m : massa (kg) (mass)

g : gravitasi $(9.8 \mathrm{~kg} / \mathrm{m} 2)$ (gravity)

h : : head (m)

- Kinetic Energy

Kinetic energy is the energy generated by the flow of water so that water rises with a certain speed, which is formulated

$\mathrm{Ek}=0,5 \mathrm{~m} \cdot \mathrm{v} \cdot \mathrm{v}$

Explanation :

Ek : Energi kinetis (Kinetic energy)

m : massa (kg) (mass)

v $\quad: \operatorname{kecepatan}(\mathrm{m} / \mathrm{s})(\mathrm{speed})$

- Mechanical Energy

Mechanical energy is the energy that arises from turbine movement. The amount of mechanical energy depends on the amount of potential energy and kinetic energy. The amount of mechanical energy is formulated:

$\mathrm{Em}=\mathrm{T} \cdot \Theta \cdot \mathrm{t}$ 


\section{Explanation :}

Em : Energi mekanis (mechanical energy)

$\mathrm{T} \quad$ : torsi (torque)

$\Theta \quad$ : sudut putar (turning angle)

t : : waktu (s) (time)

- Electrical energy

When the turbine is rotating the rotor also rotates to generate electrical energy according to the equation:

$\mathrm{El}=\mathrm{V} . \mathrm{I} . \mathrm{t}$

Explanation :

El : Energi Listrik (electric energy)

$\mathrm{V}$ : tegangan (volt)

I : Arus (ampere)

t : waktu (s) (time)

\section{f. Hydroelectric power plant using reservoirs}

This type of hydropower is similar to the hydroelectric principle that uses regulator pools. Many types of PLTA are present in countries with little rainfall, only 2-3 months, or 4 seasons countries.

The advantages of this type of hydropower is that:

- reservoirs can hold large amounts of water, so that the PLTA's hydropower generation capacity is larger.

Disadvantages of this type of hydropower are that the:

- use of a dam, consumes large capital and land and that it.

- can sometimes cause fatal changes or environmental damage

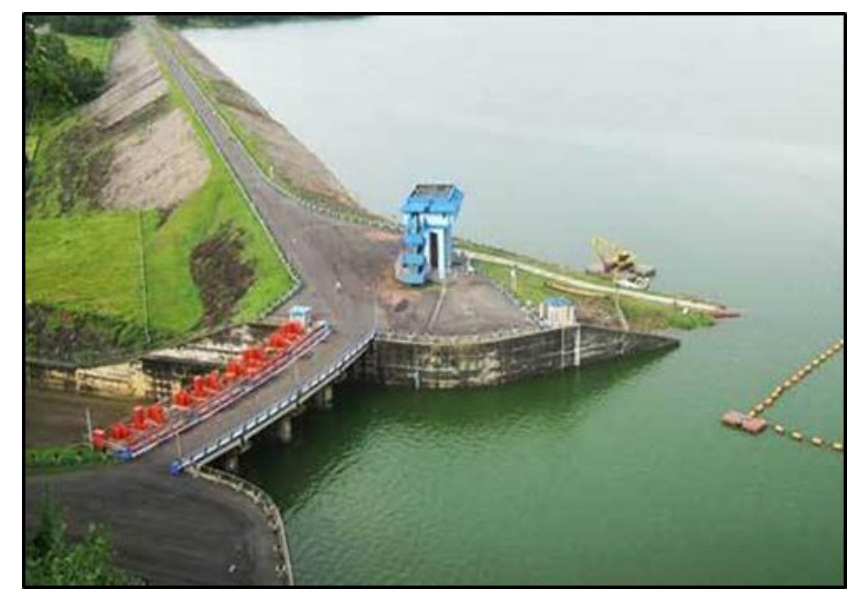

Figure. 3 of hydropower plants that uses a dam

\section{g. Operation and Operation Pattern of Reservoir}

Reservoir operation is a stream of water flowing into a reservoir and the discharge of the water that was accommodated for a particular purpose. The pattern of operation is the operational benchmark of the period of a reservoir where the water discharge issued by the reservoir must follow the requirements to maintain its elevation in accordance with the design.

\section{Result and Discussion}

Besides its main function as flood controller, the Gajah Mungkur Reservoir or Wonogiri Reservoir is also a useful area for development. One important aspect in the development of the area in question is the availability of electricity for the community. The source of electrical energy is one of the most important things for the development of the region, especially the development of urban areas. With the availability of electric energy, Wonogiri Multipurpose Reservoir will produce 12.4 MW which is expected to change the life of the surrounding community. This power will be realized in 1982 which will first be flown to Wuryantoro area. Wuryantoro area at that time already had an electricity network. 
The addition of electric energy from the Wonogiri Reservoir is the supply of electric current from Palur Karanganyar to Wonogiri Regency. The remaining excess power generated by the Gajah Mungkur hydro power plant is absorbed by Central Java region for electricity program to enter the village. The start-up phase of the operation of the electric power generated will be limited to 6 hours since the water content is primarily intended for irrigation of rice fields. If both activities are held for 24 hours it is feared that the volume of water in the reservoir will quickly shrink and run out.

Gajah Mungkur Reservoir is a reservoir located $3 \mathrm{~km}$ south of Wonogiri district, Central Java province. This artificial lake is made by stem the longest river on the island of Java, the Bengawan Solo River. The reservoir, which covers an area of 9,700 hectares in 7 districts, can irrigate 23600 ha of paddy fields in Sukoharjo, Klaten, Karanganyar and Sragen areas, the length of the dam reaches 1,452 meters, 42 meters of reservoir and 730 million meters $^{3}$. To build these reservoirs, the government moved the displaced villagers with transmigration of bedol villages to Sitiung, West Sumatera Province.

Sedimentation became a serious problem when in 2007 and 2008 there was an even flood that hit the Bengawan Solo river basin area. That's because the sedimentation causes the retreating of the reservoir which impacts on the diminishing capacity of the Gajah Mungkur Reservoir. The sedimentation that goes into the Gajah Mungkur Reservoir is derived from the erosion of rivers that empty into the reservoir including Keduang River, Wiroko, Solo Hulu, Alang and Sungai Wuryantoro. Of the five rivers, Keduang River is the largest sediment contributor at 1.218.580 $\mathrm{m}^{3}$ per year, followed by the Upper Solo River reaching 604,990 $\mathrm{m}^{3}$ per year. The high sedimentation that comes from Keduang River forms the surface of the land that extends and splits the Gajah Mungkur Reservoir with a length of more than one kilometer.

Sources of sedimentation and erosion entering the Gajah Mungkur Reservoir are derived from soil surface erosion, cliff erosion, slope avalanches, river bank erosion, and road side erosion. Felling of trees in the catchment area of either community forest, perhutani, green belt (Green belt), agricultural land, fields, will cause the erosion of the soil surface to increase so that the flow of water carries mud into the rivers that empty into the reservoir. This is further exacerbated by the destruction of Watershed (DAS), which is a tidal agricultural land that is controlled by the community for planting rice and Malawi in the dry season. The Watershed should be a green area to prevent soil erosion in the event of a flood. Sedimentation rate to the center of the dam is higher if the reservoir area is made up for tidal land to grow crops; during planting soil will easily erode when rain falls. $92 \%$ of the sediments entering the reservoir is derived from surface soil erosion.

A number of ravines and avalanches in the catchment area, slopes (cliff) area of Watershed (DAS) during rainy season erode into the reservoir. The creation of new roads by cliff dredging and rock mining by communities around the reservoir and river sites also facilitates erosion. Regardless, the Gajah Mungkur hydro power plant that is currently managed by PT. Indonesia Power PLN subsidiary is expected to remain operational for up to 100 years to come.

\section{HANDLING SEDIMENTATION}

The role of the community in the entire 
catchment area is to refrain from cutting down trees and, destroying the Green belt and, to replant around the reservoir in order to maintain the rate of erosion into the reservoir. The watershed should also be used as agricultural land. Dredging on sediments should be carried out on a regular basis. The behavior pattern of society can be changed to one of care for the reservoir by giving counseling continuously to generate an attitude of belonging to reservoir Gajah Mungkur. If concrete stakes are made in upstream Keduang, the flow of Kali Keduang can be diverted to stay away from the intake. Finally, Not garbage should not be disposed into the river because the water drains in the reservoir will be compressed.

\section{Conclusion and Recomendation}

The Hydro Power Plant (PLTA) is the main power plant in Indonesia. The hydroelectric power plant is a power plant that uses water flow as a power plant by changing the energy of water flowing (from dam or reservoir) into mechanical energy (with the help of water turbines) and from mechanical energy into electrical energy (with the help of generators). The main components in the hydropower plant are the dam, turbine, generator, and transmission line. The amount of hydropower available from a water source depends on the amount of head and water discharge.

The Hydro Power Plant is one of the potential generators to be used because it is a plant that uses renewable resources. This is especially useful in Indonesia which has a tremendous potential for using hydropower. The amount of energy that can be generated by hydropower is great and can help meet the needs of electricity supply in Indonesia.

It is hoped that the government will pay more attention to the maintenance and process of hydroelectric power plants in order that they can to be used for many years to come.

\section{Result and Discussion}

Thank you for the guidance of Mr. Yohannes Sardjono as a lecturer in environmental, energy technology, creative courses that has directed the way of writing this journal task.

\section{REFERENCES}

F. Kawamura, M. Miura, R. Ebara, K. Yanase. 2016. Material Strength oOf Long-t Term Used Penstock oOf a Hhydroelectric Power Plant. Instituate of Materials Science and Technology, Fukuoka University, Japan.

André L. L. Reda, Fernando de S. Viña, Raphael L. F. Alves, Renato G. C. Ribeiro. 2016. Santo Antônio Hydroelectric Power Plant Reservoir Life Time: An Independent Sediment Budget Estimate oOn tThe Madeira River, Brazil.

Mustafa Gogusa, A. Burcu Altan-Sakaryaa, Mete Kokena. 2016. Experimental Investigation of the Original Project of Yukari Kaleköy Dam and Hydroelectric Power Plant Spillway. Procedia Engineering 161 (2016) $313-317$.

Temelsu, 2013. Upper Kaleköy Dam and Hydroelectric Power Plant, Hydraulic Calculations.

Setiawan D., 2013. Kajian Pengaruh Perubahan Iklim dan Tata Guna Lahan di Daerah Aliran Sungai (DAS) Citarum Hulu terhadap Pembangkit Listrik Tenaga Air Saguling Assessing the impact of climate change and landuse change in Upper Citarum Watershed to Saguling Hydropower]. Bogor Agricultural University.

Setiawan., 2014., Potential Sites Screening for Mini Hydro Power Plant Devenlopment in Kapuas Hulu, West Kalimantan : a GIS approach, Energy Procedia.

Rajeswari V, Rajeshwari Y and Padma Suresh L 2012 Real-Time Implementation of 
Hydroelectric Power Plant Using PLC and SCADA, Internastional Journal of Engineering Research and Applications 2(3) 899-902.

Gupta R, Singh S N and Singal S K. 2012. Automation of Small Hydropower Station, International Conference on Small Hydropower - hydro, Sri Lanka, October 22-24, pp 1-9.

Popa B and Paraschievescu. 2012. Introduece in utilizarea energie apelor, Editura Politehnica Press, Bucuresti, Romania.

Dinis C M and Popa G N. 2014. Measurements in SCADA System Used at a Wastewater Treatment Plant Annals of Faculty Engineering Hunedora International Journal oOf Engineering 207-215.

Kaur S, Kathpal N and Munjal N. 2015. Role in Hydro Power Plant Automation, International Journal of Advanced Research in Electrical, Electronics and Instrumentation Engineering 805-809.

Temelsu, 2013. Upper Kaleköy Dam and Hydroelectric Power Plant, Hydraulic Calculations.

Knauss, J. 1987. Swirling Flow Problems at Intakes, A.A. Balkema, Rotterdam.

Altan-Sakarya, A.B., Köken, M., Yavuz, C., Dinçer, A.E., 2014. YukarÕ Kaleköy dam and hydroelectric power plant spillway hydraulic model studies. Final Report. Middle East Technical University, Ankara, Turkey.

Carvalho N. O.; Júnio N. P. F.; Santos P. M. C.; Lima J. E. F. W. "Guia de avaliação de assoreamento". Brasília: Agência Nacional de Energia Elétrica. 2000, 107p. Available on:

Viña, F.S.; Alves, R.L.F.; Ribeiro, R.G.C. "Transporte de sedimentos em rios e seus impactos sobre reservatórios". Dissertation (Civil Engineering), Engineering School, Mackenzie Presbyterian University, São Paulo. 2013, 110p.
Santoso Samosir Cahyo. 2012. Optimasi Pola Operasi Waduk Untuk Memenuhi Kebutuhan Energi Pembangkit Listrik Tenaga Air (Studi Kasus Waduk Wonogiri). Fakultas Teknik, Universitas Brawijaya, Malang, Jawa Timur, Indonesia.

Sri Utami. 2015. Pembangunan Waduk Gajah Mungkur Tahun 1976-1986. Fakultas Ilmu Sosial Universitas Negeri Surabaya.

Wiryanto., 2012. Model Pengelolaan Per Waduk Berdasarkan Tingkat Kesuburan Pencemaran Air.

Fauziah Eellys. 2012. Agriekonomika Jurnal Sosial Ekonomi Dan Kebijakan Pertanian. Program Studi Agribisnis Fakultas Pertanian Universitas Trunojoyo Madura.

Miroslav B., Michaela D Jan S., 2012. Determinatination of Unit Hydrograph Parametes For Indiana Watersheds, TRB Subject 23-6 Erosion and Water Pollution Control .

Elbashir S., 2011. Flood Routing in Natural Channels Using Muskingrum Methods Disserta submitted in partial fufillment of the requirements for the Dublin Institute of Technology's Master of Engineering Computation. 2011

Sardoii E. R., Rostami N. 2012. Calibration of loss estimation methods in HEC-HMS for simulation of surface runoff (Case Study : Amirkabir Dam Watershed, Iran) Advances in Environmental Biology. 6(1) : 343-348.

Ostojic G., Stankovski., Maksimovic R., 2013. Development of hydro potential in Republic Srpska, RFenewable and Sustainable Energy Reviews Volume 28, December 2013, Pages 196- 203.

https://sdmuhammadiyah2solo.wordpress.com/2 011/11/24/pembelajaran-pengenalanlapangan-kelas-vi-pembangkit-listriktenaga-air-di-bendungan-wonigiri/ https://www.slideshare.net/adindagifary/fisikaterapan-prakarya-pembangkit-listriktenaga-air

http://hendripemudadesa.blogspot.co.id/2014/04 /makalah-plta.html 
http://misbahulilmi.blogspot.co.id/2015/10/m akalah-pembangkit-listrik-tenagaair.html

https://media.neliti.com/media/publications/2 9482-ID-kontribusi-usahatani-lahansurutan-bendungan-serbaguna-wonogiriterhadap-kesejah.pdf

http://infocom-hmjtsuty.blogspot.co.id/2011/09/analisiswaduk-gajah-mungkur.html

Anonim1. 2013. Pembangkit Listrik Tenaga Air. (http://teknik-listrikunbari.blogspot.com/2013/02/pembangki t-listrik-tenaga-air.html, diakses 16 Mei 2013).

Anonim2. 2013. Pembangkit Listrik Tenaga

Air.

(http://www.anneahira.com/pembangkitlistrik-tenaga-air.htm, diakses 16 Mei 2013).

Anonim3. 2013. Cara Kerja Pembangkit Listrik Tenaga Air. (http://4bri.blogspot.com/2012/11/carakerja-pembangkit-listrik-tenaga.html, diakses 16 Mei 2013).

Anonim4. 2011. Pembangkit Listrik Tenaga Air PLTA altenatif Energi Masa DepanIndonesia.(http://indone5ia.wordp ress.com/2011/05/13/pembangkit-listriktenaga-air-plta-alternatif-energi-masadepan-indonesia/, diakses 16 Mei 2013) 